\title{
Preventing the Regulatory Chill of International Investment Law and
} Arbitration

\author{
Dr. Atif M. Alenezi ${ }^{1}$ \\ ${ }^{1}$ School of Law, University of Manchester, Manchester, United Kingdom \\ Correspondence: Dr. Atif M. Alenezi, Riyadh, Saudi Arabia. E-mail: atifalenezi@gmail.com
}

Received: September 11, 2020

Accepted: October 11, 2020

Online Published: October 15, 2020

doi:10.5539/ilr.v9n1p85

URL: https://doi.org/10.5539/ilr.v9n1p85

\begin{abstract}
International investment law has increasingly come under attack because it does not put host states on par with foreign investors. Foreign investors can evoke broad investment rights and pursue investment arbitration. The threat of substantial arbitral awards can result in host states not enacting policies, regulations, laws or reaching decisions, despite them being needed in order to protect a variety of important public interests. The concern is, therefore, that international investment law, including the investor-state dispute resolution system, causes a regulatory chill. The paper examines how the asymmetric relationship between foreign investors and host states can be remedied, so that trust in international investment law is strengthened and its legitimacy crisis is overcome. One core issue with international investment law is that the customary international minimum standard and its therein subsumed full protection and security, and fair and equitable treatment and compensation principles are inherently vague, thereby contributing to the overprotection of foreign investors. Arbitral cases further highlight how regulatory changes can result in host states incurring liability and thus enable foreign corporations to shift potential costs and risks. International, and national solutions to prevent the regulatory chill of international investment agreements are spelled out.
\end{abstract}

Keywords: foreign direct investment, regulatory chill, investor state dispute settlement, international investment agreement

\section{Introduction}

\subsection{Background}

Many bilateral investment agreements ('BITs'), free trade agreements ('FTAs) and international investment agreements ('IIAs') contain investor-state arbitration frameworks. ${ }^{1}$ Investor-state dispute settlement ('ISDS'), i.e. investment treaty arbitration proceedings may be brought by a foreign investor on the basis that a government enacted a law, policy or engaged in decision-making which lowered the worth of a foreign investment (Alvarez, 2016). In case a foreign investor succeeds with evidencing that its investment rights were breached, it could potentially be awarded unrestricted sums of compensation (Public Citizen, 2001). Compensation can be significant, as illustrated by Dow Chemical v. Kuwait ${ }^{2}$, where the host state was ordered to pay $\$ 2.5$ billion (Páez-Salgado, 2015). Also, in Exxon Mobile v. Venezuela ${ }^{3}$, Venezuela was ordered to pay $\$ 1.6$ billion, although the $\$ 50$ billion Yukos award ${ }^{4}$ is by far the largest arbitral award (Páez-Salgado, 2015).

\subsection{The Importance of Preventing a Regulatory Chill}

Governments may fear that arbitration panels award significant damages to multinational corporations and opt for not enacting needed regulation (Nagy, 2020). Hence, the public interest may suffer because a state does not opt to further, e.g. environmental, health, corporate social responsibility, or sustainable development objectives, as it may otherwise expose taxpayers to significant legal liability (Thakur, 2020; Ji, 2018). Consequently, the term "regulatory chill" refers to legislators not passing legislation or taking regulatory action which adversely impacts foreign investments (Nagy, 2020). In other words, states may alter their behaviour in order to avert investor-state

\footnotetext{
${ }^{1}$ UN General Assembly (2015, August 5). Promotion of a democratic and equitable international order: Note by the Secretary-General, A/70/285. Retrieved from https://www.refworld.org/docid/55f28f2e4.html

${ }^{2}$ Petrochemical Industries Companies (K.S.C.) v The Dow Chemical Company [2012] EWHC 2739.

3 Venezuela Holdings and others v. the Bolivarian Republic of Venezuela, ICSID Case NO. ARB/07/27 (10 June 2010).

${ }^{4}$ Russian Federation v Yukos Universal Limited, UNCITRAL, PCA Case No. 2005-04/AA227 ,Final Award )18 July2014).
} 
disputes (Bonnitcha, 2014).

\subsection{The Chasm within the Scholarly Literature}

The existing literature is divided on whether investment treaties cause a regulatory chill (Bonnitcha, 2014). It is inherently difficult to attribute the non-existence of laws, regulations or government decisions to regulatory chilling, as there can be other causes for not opting for regulations, such as a preference for neo-liberal deregulation (Bonnitcha, 2011). Bonnitcha (2014) also points out that it is unclear whether government legislators actually consider that passing a law or taking certain regulatory actions may result in investor arbitration being pursued and a possible significant arbitral award being made against the state. Also, not every law which is being adopted will be challenged by a foreign investor (Janeba, 2019). Further, Schill avers that investment treaties do not impede a state from enacting regulation unilaterally in order to combat climate change in so far as the regulatory measures are reasonable and proportionate (Schill, 2007). Janeba (2019) also explicates that the chance that an arbitral panel errs in favour of a foreign investor or a host state is equal. Furthermore, high arbitral costs and a good arbitral institution "arguably only result in legitimate claims being filed", thereby preventing "frivolous lawsuit[s]...which lead... to regulatory chill" (Janeba, 2019: 15\&20).

In contrast, others argue that comprehensive investor protections coupled with a private dispute settlement procedure are "an extraordinary attack on normal government activity" because governments can be pursued, for instance, for implementing environmental agreements or refusing a permit on health and safety grounds (Public Citizen, 2001). Similarly, Johnson and Volkov (2014) state that investment treaties enable powerful corporations to alter the substantive law and avoid their legal duties under domestic laws, as well as judicial frameworks which could otherwise enforce domestic laws. Ji (2018) also explicates that the public welfare will be harmed if host states were deterred from enacting comprehensive legislation which promotes the public interest.

There thus exists a chasm within the literature, as some favour the "Classic Paradigm", under which the sole purpose of investment treaties is to protect vulnerable foreign investors against the untrammelled exercise of sovereign power (Laborde, 2010). Under this classic model, it is the foreign investor which is afforded rights and can bring an investment arbitration dispute against the host state by evoking the provisions in a BIT, FTA, IIA or investment contract (Laborde, 2010). Foreign investors are granted these "private rights of action" in order to overcome the "substantial risk to their investments" (Posner \& Sykes, 2012: 294). Host states arguably benefit from this since foreign investors charge lower risk premia and consequently the cost for importing capital is not as high (Posner \& Sykes, 2012). To date, the great majority of IIAs are reflective of this classic paradigm since they were concluded prior to 2008 , during which time the main objective of a treaty was to provide enhanced protection to foreign investors (UNCTAD's Reform Package, 2018).

However, the classic paradigm has been increasingly criticised since it unduly favours "the interests of foreign investors vis-à-vis the interests of all other constituencies in society" (Arcuri, 2017: 1). This is because international investment law permits an asymmetric relationship under which the foreign investor is granted substantial rights, whereas host states and their communities are not afforded similar rights (Arcuri, 2017). As a result, sustainable development can suffer in host states which cannot adequately promote public interest objectives, such as environmental protection, preservation of natural resources, as well as social well-being (UNCTAD's Reform Package, 2018). Opponents of the classic paradigm, therefore, advocate a "Reverse Paradigm" under which the host state can also rely on contract and/or treaty provisions in order to pursue a foreign investor (Laborde, 2010: 97). This paradigm reflects that more and more states consider that the international investment law framework is inherently 'imbalanced' (Thakur, 2020).

\subsection{The Objective and Argument of this Article}

It is against this background that this paper seeks to identify solutions which prevent the regulatory chill of investment agreements. For this purpose, it is firstly explored how the customary international minimum standard of treatment has become supplanted by the full protection and security ('FPS'), fair and equitable treatment ('FET'), as well as the effective, due and prompt compensation principles (Chimni, 2019). It is emphasised that these broad principles can be exploited by foreign investors in order to expand the protective reach of investment agreements. Thereafter, case examples are referred to in which liability was imposed on host states which changed their laws and regulations, or which experienced regulatory chilling. Subsequently, it is addressed how the regulatory chill of investment agreements can be prevented before the paper concludes. It is argued that the time has come to rebalance international investment law in accordance with the rationale of the reverse paradigm, so that the interests of stakeholders other than corporate entities are also recognised as requiring protection. 


\section{The Research Methodology and Method}

The research methodology underlying this paper is rooted in positivism (Meyerson, 2009). This theoretical perspective considers that knowledge can be derived from empirical observation (Meyerson, 2009; Hervey et al., 2011). As this constitutes legal research, it is particularly assumed that knowledge can be identified from objective facts, particularly posited law (Meyerson, 2009). Such doctrinal research is particularly employed in order to identify relevant laws and, therefore, serves as an important foundation (Hervey et al., 2011).

\subsection{Positivism and Postpositivism}

The complexity which exist when ascertaining truth is acknowledged and methodological pluralism is embraced in accordance with postpositivist thought (Vinod \& Deshpande, 2013). For instance, moral and normative issues are being probed, including whether foreign investors - the current beneficiaries of international investment law should owe duties to host states and their communities (García-Salmones Rovira, 2015). Hence, as "the rule of law...[is] a moral ideal", legal rules are considered critically through the lens of idealism and a "system of natural rights; [as well as] an empirically-minded version of...legal positivism..." (Coyle, 2006: 257). Also, post-positivism recognises the value which empirical data can have in terms of further describing the research phenomenon (Edwards \& Holland, 2013) and brief recourse was, therefore, also made to qualitative interviews conducted by Côté (2014) and empirically-oriented research by Tienhaara (2011). Nonetheless, the ontological and epistemological orientation is predominantly rooted in positivism, but the interpretivist position is also deemed useful (Bryman, 2010).

\subsection{The Research Method}

In terms of the research method, a black letter law approach was employed and relevant primary sources (e.g. treaties and cases) were identified, as well as secondary legal sources, such as books and scholarly articles (Hutchinson, 2013), as well as non-legal sources, e.g. international relations (Côté, 2014) and health care literature (Gilmore et al., 2006).

\section{The Customary International Minimum Standard and Its Customary Principles: How Vagueness Benefits Foreign Investors}

ISDS clauses empower foreign investors to privately enforce their investment rights (Public Citizen, 2001). These investment rights can be based on BITs, FTAs, IIAs, contracts, host state law, as well as the customary international minimum standard of treatment which emerged during colonial times (Joubin-Bret, 2008; Collins, 2017). This minimum standard developed from international law generally recognising that a wrong committed against an alien incurs state responsibility, i.e. that foreign investors are protected by the international law concept of diplomatic protection and the rules on state responsibility (Sornarajah, 2017).

\subsection{The Customary International Minimum Standard of Treatment}

The customary ${ }^{5}$ international minimum standard of treatment binds host states and offers a minimum level of protection to foreign investors against "a relatively higher degree of inappropriateness." ${ }^{6}$ For instance, "an international delinquency... [may be constituted if the act causes] an outrage, [was done in] bad faith, [or amounts] to wilful neglect of duty, or...an insufficiency of governmental action [and falls] short of international standards that every reasonable and impartial man would...recognize..." Although the substance of this standard continues to be "largely contentious" (Mantilla Blanco, 2019). Yet despite its specific elements being contested, this standard has been substituted by three customary principles: Full protection and security ('FPS'), fair and equitable treatment ('FET'), as well as effective, due and prompt compensation (Chimni, 2019).

\subsection{FPS}

Traditionally, the FPS standard covers "situations where the physical security of the investor or its investment is compromised." However, the exact content and scope of the FPS standard is "somewhat uncertain" (Mantilla Blanco, 2019: 10). For instance, it has been observed that this standard also requires host states to safeguard intangible assets. .9 Moreover, it has been found that the FSP standard obligates the host state "to ensure that neither by amendment of its laws nor by actions of its administrative bodies is the agreed and approved security and

\footnotetext{
${ }^{5}$ Article 38(1)(b) of the Statute of the International Court of Justice.

${ }^{6}$ Saluka Investments BV v. The Czech Republic, PCA Case No. 2001-04, Partial Award (17 March 2006) para.292.

${ }^{7}$ LFH Neer and Pauline Neer (USA v. United Mexican States) (1926) IC RIAA 60, 61f.

${ }^{8}$ BH Group Plc. v. The Republic of Argentina, UNCITRAL, Final Award (24 December 2007) para.324.

${ }^{9}$ Siemens A.G. v. The Argentine Republic, ICSID Case ARB/02/8, Award, 6 February 2007, para.303.
} 
protection of the foreign investor's investment withdrawn or devalued."10 FPS thus also deals with "legal harms", but there exist no categories of legal harms, so that the scope of acts which may be caught by this standard is unlimited (Junngam, 2018: 100). There is also an overlap with the FET, thereby further broadening the rights of foreign investors (Junngam, 2018).

\subsection{FET}

The FET principle has been found to confer far-reaching substantive and procedural safeguards (Newcombe $\&$ Paradell, 2009). This standard is vague since its meaning has not been precisely defined (Kläger, 2011). Also, the liability threshold is rather low (Hindelang \& Krajewski, 2016). As a result, foreign investors can fill protective gaps, even in circumstances where they would otherwise be unable to demonstrate that they had been subjected to expropriation or discriminatory treatment (Alvarez, 2016). FET does not adequately guide governments, but instead empowers foreign investors to seek protections which do not exist under domestic law by conferring significant interpretive discretion to arbitrators (Alvarez, 2016). This arguably raises legitimacy questions, including because international investment law does not sufficiently address "ideas of distributive justice and equity" in respect of safeguarding the public interest of host states (Kläger, 2011; Franck, 1998: 6).

\subsection{The Hull Formula}

Under the customary principle of compensation, also known as the Hull formula, "prompt, adequate and effective" compensation is payable (Ripinsky \& Williams, 2008: 72). Expropriation has been broadly defined, for instance, it extends "not only [to] open, deliberate and acknowledged takings of property [but also] to "covert or incidental interference with the use of property." 11 Regulatory takings ${ }^{12}$ are also included, thereby making it more challenging for host states to further "socially desirable" objectives (Cotula, 2011: 145-146). Hence, conceptual uncertainty also exists in respect of exactly defining indirect expropriation, despite many disputes being brought on the basis that there was an indirect expropriation (Janeba, 2019). Also, this formulation has been interpreted as requiring "full" 13 but also "adequate" 14 compensation, highlighting that the exact standard remains disputed (Babu, 2014).

\subsection{Finding the Right Balance between Protecting Investor Rights and the Right to Regulate}

While the regulatory discretion of host states should not be unlimited, the right balance must be struck between upholding investor rights and government policy flexibility (Posner \& Sykes, 2012). As pointed out by Posner and Sykes (2012: 297), the principles governing investment arbitration are insufficiently tailored to realise an "intermediate position" which overcomes the existing "tension between...protecting investors...and....host countries". The next section discusses cases in which commercial disputes impacted "public law matters", including the rights of communities (Butler \& Subedi, 2017) and, thereby, illustrates this inherent tension, which if unbalanced can lead to a regulatory chill.

\section{Regulatory Change and the Threat of Host State Liability}

Foreign investors have been awarded compensation by arbitral tribunals in numerous cases where governments changed their regulatory frameworks (Johnson \& Volkov, 2013). Such an approach has been facilitated by "Washington Consensus economics that give primacy to [foreign investors and] ...deny governments the policy space required to manage and regulate their own development (Alavarez \& Sauvant, 2011: 24). As observed in Frontier Petroleum Services Ltd. v. Czech Republic ${ }^{15}$, investors can rely on direct or indirect promises which the host state has made by virtue of "legislation, treaties, decrees, licenses, and contracts."16 For example, regulatory measures and actions can be construed as "exproprietary acts" in circumstances where "such actions or measures are [not] proportional to the public interest presumably protected thereby and the protection legally granted to investments." 17 In other words, a broad gamut of pledges can be construed as binding promises and an equally wide variety of actions can possibly violate the "commitments", thereby significantly extending the scope of

${ }^{10}$ CME Czech Republic B.V.v. The Czech Republic, UNCITRAL, Partial Award, (13 September 2001) para.613.

${ }^{11}$ Metalclad Corporation v. United Mexican States, ICSID Case No. ARB(AF)/97/1, Award of 30 August 2000, para.103.

${ }_{12}$ Pope \& Talbot Inc. v. Government of Canada, Award on the Merits of Phase 2, 10 April 2001, para.100.

13 Chorzów Factory (Germany v. Poland), 1927 P.C.I.J. (ser. A) No. 9 (26 July) at 21.

${ }_{14}$ Texaco Overseas Petroleum Company/California Asiatic Oil Co. v. Government of the Libyan Arab Republic, Award of 19 January 1977, 17 ILM 1 (1978) paras. 81-87.

${ }^{15}$ Frontier v. Czech Republic, UNCITRAL, Final Award, (12 November 2010).

16 Ibid at para.285.

${ }^{17}$ Técnicas Medioambientales Tecmed S.A. v. The United Mexican States, ICSID, Case No. ARB(AF)/00/2, 2004, 43 I.L.M. 133 , para.122. 
possible and actual liability host states may incur (Johnson \& Volkov, 2013: 381).

\subsection{Cases Dealing with Regulatory Change and Economic Matters}

In CMS Gas Transmission Company v. Argentina ${ }^{18}$, Argentina adopted regulatory measures against the collapse of its economy, but these were found to breach its BITs (Kanetake \& Nollkaemper, 2016). Also, the damages award of US\$ 133 million plus interest against Argentina was upheld, despite it being found during subsequent annulment proceedings that the arbitrators had made errors of laws in respect of Argentina's argument of necessity (Ripinsky \& Williams, 2008). Damages in excess of $\$ 100$ million were also awarded in $L G \& E v$. Argentina ${ }^{19} ; E D F I v$. Argentina $^{20} ;$ BG Group v Argentina ${ }^{21}$; and National Grid v. Argentina ${ }^{22}$ (Johnson \& Volkov, 2013). Furthermore, in Occidental Petroleum Corporation v. Ecuador ${ }^{23}$, Ecuador had enacted a windfall profit tax which was found to be in breach of a FET provision in its BIT, which had created a legitimate expectation to keep the tax regime stable (Scherer, 2018). The tribunal awarded over $\$ 1.7$ billion against Ecuador, although this was later reduced to $\$ 1.1$ billion $^{24}$ (Páez-Salgado, 2015).

\subsection{Cases Dealing with Regulatory Change and Safeguarding the Public Interest}

Host states have also been unable to uphold important rights which are in the public interest, such as the right to health ${ }^{25}$ and the right to water ${ }^{26}$, since BITs are underpinned by "an absolute investment protection rationale" (Morosini \& Sanchez Badin, 2018: 11). For instance, when the Argentine government warned residents not to drink contaminated water and passed regulations which proscribed that residents could be requested to pay for the water during the water crisis, the foreign corporation, which operated the facilities, successfully brought arbitration proceedings and was awarded over $\$ 100$ million in compensation ${ }^{27}$ (Miles, 2013). This pro-investor attitude is further evidenced by a case where the tribunal rejected considering the environmental objective which led to the expropriation when calculating damages ${ }^{28}$ (Suda, 2006).

\subsection{NAFTA Cases and Regulatory Change}

In the North American Free Trade Agreement ('NAFTA') case, S. D. Myers v. Canada ${ }^{29}$, Canada banned the export of toxic polychlorinated biphenyl waste. The foreign corporation claimed that this prevented it from business activities in Canada. Canada was found to have breached Articles 1102 and 1105 of NAFTA because US waste disposal corporations had been treated less favourably. Also, in Methanex v. U.S. ${ }^{30}$, gasoline oxygenate methyltertiary-butyl ether was banned because of its adverse impact on the environment and human health (Mitchell et al., 2016). While this claim did not succeed, the regulatory measure which had been adopted to advance important public interest concerns, nonetheless, formed the basis for an arbitration (Mitchell et al., 2016).

In the NAFTA case Metalclad Corporation v. Mexico ${ }^{31}$, a US business purchased a Mexican corporation which owned land near a municipality (Sasse, 2011; Urueña, 2012). The Mexican corporation was acquired in order to develop a toxic waste landfill on the land and there appeared to have been assurances by officials that relevant permits would be granted. However, the governor and the municipality imposed an order to stop any work as a permit had not been granted. Subsequently, the permit was obtained, and the project was completed. However, demonstrations ensued, and the municipality refused to grant the permit. Also, an ecological decree was passed which declared the land to constitute a natural reserve, thereby barring operations indefinitely. The tribunal ruled

\footnotetext{
${ }_{18}$ CMS Gas Transmission Company v Argentina, ICSID Case No. ARB/01/8, Award, (Orrego Vicuna, Lalonde, Rezek) (12 May 2005).

${ }^{19} L G \& E$ v. Argentina ${ }^{19}$, ICSID Case No. ARB/02/1, Decision on Liability, (de Maekelt, Rezek, van den Berg) (3 October 2006).

${ }^{20}$ EDFI v Argentina ${ }^{20}$, ICSID Case No. ARB/05/13, Award, (Bernardini, Rovine, Derains) (8 October 2009).

${ }^{21}$ BG Group v Argentina ${ }^{21}$, Ad Hoc, UNCITRAl, Final Award, (Alvarez, van den Berg, Garro) (24 December 2007).

${ }^{22}$ National Grid v. Argentina ${ }^{22}$, Ad Hoc, UNCITRAL, Award, (Sureda, Kessler, Garro) (3 November 2008).

${ }^{23}$ Occidental Petroleum Corporation and Occidental Exploration and Production Company v. Republic of Ecuador, ICSID Case No. ARB/06/11, Award, (Fortier, Williams, Stern) (5 October 2012).

${ }^{24}$ Occidental Petroleum Corporation and Occidental Exploration and Production Company v. Republic of Ecuador, Decision on Annulment, ICSID Case No. ARB/06/11) (2 November 2015); Páez-Salgado n 5.

${ }^{25}$ Chemtura Corporation v Government of Canada, Award, NAFTA/UNCITRA1, 2 August 2010; Ethyl Corporation v The Government of Canada, Award on Jurisdiction, NAFTA/UNCITRAL, 24 June 1998.

${ }^{26}$ Compañia de Aguas del Aconquija S.A. and Vivendi Universal S.A. v Argentine Republic, Award, ICSID Case No. ARB/97/3.

27 Azurix Corporation v. Republic of Argentina, ICSID, Case No. ARB/01/12, Award of 14 July 2006, para.430.

${ }^{28}$ Compania del Desarrollo de Santa Elena S.A. v Republic of Costa Rica (2000) 39 ILM 317.

29 S.D. Myers Inc. v. Government of Canada, UNCITRAL, Partial Award of 13 November 2000.

${ }^{30}$ Methanex Corporation v. United States of America, NAFTA Chapter 11, Final Award on Jurisdiction and Merits, 3 August 2005.

${ }^{31}$ Metalclad Corporation v. United Mexican States, ICSID Case No. ARB(AF)/97/1.
} 
that the actions of Mexico constituted an expropriation and that the FET standard had been breached (Urueña, 2012). However, the case does not establish that host states cannot adopt regulatory measures, but simply demonstrates that host states must pay compensation to the foreign investors which cannot use the property as intended (Mann, 2018). Nonetheless, the case highlights that host states are placed "into an impossible situation in terms of making new regulations" (Mann, 2018).

\subsection{An Example of the Regulatory Chill Following the Threat of Arbitration}

For instance, when the Indonesian government enacted a ban against open-pit mining in areas of protected forests, foreign-owned corporations threatened that they would pursue international arbitration on the basis that the ban amounted to an indirect expropriation which breached the FET standard (Suda, 2006). As a result of this threat, Indonesia firstly exempted various companies and later repealed the ban because of the government's inability to pay compensation (Suda, 2006).

\subsection{A Potential Regulatory Chill for Court Decisions}

In Eli Lilly v. Canada ${ }^{32}$, the foreign investor even challenged the legal decisions of Canadian courts dealing with intellectual property law (Johnson \&Volkov, 2014). The investor averred that the way in which the courts interpreted the law unduly altered the legal regime of the host country in breach of its "legitimate expectations" 33 (Johnson \& Volkov, 2014).

\subsection{Concerns Regarding Investor-State Arbitration}

Alvarez and Sauvant (2011) note that the rise in significant awards against developing countries demonstrates that investor-state arbitration is marred by concerns about legitimacy, accountability, transparency, sound governance and the rule of law. Nonetheless, while these cases support the argument that ISDS can result in a regulatory chill, there exist scarce empirical evidence which establishes whether this problem is endemic or only occurs in isolated cases (Berge \& Berger, 2020). Although Sattorova (2019) refers to empirical case studies conducted by Tienhaara (2011) and Côté (2014) which suggest that host states are concerned about the impact which foreign investors can have. Also, Sattorova (2019) observes that foreign investors can reinforce poor governance since regulatory capture, bribery and corruption become normalised, as suggested by Gilmore et al. (2006) and Knight and Chapman (2004). Privileging the private rights of foreign investors results in a risk transfer to host states, particularly to taxpayers (Johnson \& Volkov, 2013; Johnson \& Volkov, 2014). Consequently, foreign investors are not required to prevent costs and risks which possible future legislation tries to combat, but can instead pressurise host states into not adequately advancing pivotal public interest concerns, such as social welfare, environmental protection and good governance (Johnson \& Volkov, 2013). Such a position undermines trust in the international investment framework (Dugan et al., 2008), which is further evidenced by various Latin American countries withdrawing ${ }^{34}$ from the ICSID system and several BITs (Boeglin, 2013). The next section spells out solutions which may help with preserving the regulatory, policy and legislative space of host states, while still providing protection to foreign investors.

\section{International, Regional and National Solutions to Carve out More Regulatory Space}

Investment disputes deal with public issues, but, nonetheless, a private dispute settlement procedure is being used (Butler \& Subedi, 2017). As a result, arbitrators are being granted "enormous power", as they can "mak[e] decisions about the rules that govern major portions of host country economies and, by extension, their societies" (Leader, 2006: 684). This "undermine[s] basic principles of democratic representation and accountability" (Van Harten, 2005: 600; Butler \& Subedi, 2017: 47), particularly because the customary international minimum standard is vague, as discussed above.

\subsection{A Multilateral Investment Court}

Some authors, such as Butler and Subedi (2017: 43) advocate for the creation of a "World Investment Organisation." In other words, the mistrust in investment arbitration has resulted in calls to set up "in the longer term, a multilateral investment tribunal and appellate mechanism" and to thereby also "reform...the ISDS system"35 (Croisant, 2019).

\footnotetext{
${ }^{32}$ Eli Lilly and Co. v. Canada, Notice of Arbitration, 12 September 2013, para. 82-84.

${ }_{33}$ Eli Lilly and Co. v. Canada, Notice of Arbitration, 12 September 2013, paras. 82-84.

${ }^{34}$ See Article 71 of the ICSID Convention.

${ }_{35}$ Opinion of Advocate General Bot (2019, January 29). Request for an opinion by the Kingdom of Belgium, Opinion 1/17, para. 7. Retrieved from

http://curia.europa.eu/juris/document/document.jsf?text=\&docid=210244\&pageIndex=0\&doclang=EN\&mode=1st\&dir=\&occ=first\&part=1\& cid $=10811785$
} 
The trend towards the "[j]udicialization of arbitration" (Torgal, 2020) is also evidenced by the EU and Canada creating an investment court system ('ICS') with a permanent tribunal and an appeal tribunal by virtue of the Comprehensive Economic and Trade Agreement between the EU and Canada ('CETA') (European Commission, 2014). This is an important stepping stone for the establishment of a "permanent multilateral investment court" (Turinys, 2016). Bernasconi-Osterwalder \& Johnson (2019) argue that a multilateral investment court should also have jurisdictions to hear, e.g. "state-state cases, torts cases against investors and certain types of contract cases", and should enable impacted third parties, including citizens, to join claims in order to uphold and enforce their rights and also for respondents to lodge counterclaims.

\subsection{A Multilateral Investment Agreement}

The creation of an institution, such as CETA's new investment court system, is not necessarily a guarantee that the public interests of host states are better protected. An international agreement which accommodates not only the private interests of investors, but equally the public good of host states would also need to be adopted (von Moltke, 2000). This is also important because the UNCITRAL Rules on Transparency in Treaty-based Investor-State Arbitration $2014^{36}$ only make scant reference to the "public interest in transparency" and that in this context ISDS should "take account of the public interest involved." 37

Hence, a comprehensive multilateral agreement which also clearly spells out investor obligations, as well as adequately safeguards the policy space of host states and their "public-policy interest" could be one way to remedy the shortcomings of the current international investment law framework (von Moltke, 2000: v-vi). However, it is pertinent that it is clearly defined what can fall within the public interest, i.e. the "public interest exceptions" in which investors should not be compensated should be particularised (Giest, 2017: 333-334). Put differently, the agreement would need to ensure an "intermediate position", so that a better balance is struck between protecting investors and host states (Posner \& Sykes, 2012: 297).

\subsection{CETA: A Stepping Stone for Safeguarding the Right to Regulate}

CETA is an example of a regional agreement which moves away from the "absolute investment protection rationale" (Morosini \& Sanchez Badin, 2018: 11) towards a more balanced system. For instance, the preamble of CETA recognises the right to regulate in order to realise legitimate policy aims, as well as the parties' commitment to foster sustainable development. ${ }^{38}$ Moreover, section D of CETA deals with investment protection of which Article 8.9(1) importantly

"reaffirm[s the parties'] right to regulate within their territories to achieve legitimate policy objectives, such as the protection of public health, safety, the environment or public morals, social or consumer protection or the promotion and protection of cultural diversity."

Furthermore, Article 8.9(2) clarifies that

"the mere fact that a Party regulates, including through a modification to its laws, in a manner which negatively affects an investment or interferes with an investor's expectations, including its expectations of profits, does not amount to a breach of an obligation."

Also, Article 8.9 sub-paragraphs (3)-(4) state that

"a Party's decision not to issue, renew or maintain a subsidy... in the absence of any specific commitment under law or contract... or...in accordance with any terms or conditions...does not constitute a breach", so that "nothing in [Article 8.9] shall ... prevent ... a Party from discontinuing the granting of a subsidy or requesting its reimbursement where such measure is necessary in order to comply with international obligations... or has been ordered by a competent court, administrative tribunal or other competent authority, or requiring that Party to compensate the investor...."

These provisions may go some way to act as a protective bulwark for host states and should also be included in a comprehensive multilateral agreement in order to prevent a regulatory chill or at least be included in new IIAs and old IIAs when these are modernised. However, instead of giving only some examples of values which are in the public interest, efforts should be made to comprehensively list and define them (Giest, 2017: 336). Absolute and relative public interest exceptions could also be formulated (Giest, 2017: 347). In this context, it would be desirable

36 UNCITRAL Rules on Transparency in Treaty-based Investor-State Arbitration (2014). United Nations, 1-20. Retrieved from https:/uncitral.un.org/sites/uncitral.un.org/files/media-documents/uncitral/en/rules-on-transparency-e.pdf

37 Article 4(a) and the preamble of the UNCITRAL Rules on Transparency in Treaty-based Investor-State Arbitration

${ }^{38}$ The Comprehensive Economic and Trade Agreement between Canada, of the one part, and the European Union and its Member States, February 2016, 1-1598, 3. Retrieved from https://trade.ec.europa.eu/doclib/docs/2016/february/tradoc_154329.pdf 
to clarify when the vague customary international principles discussed above can be derogated from and what the limits of these principles are, e.g. that foreign investors cannot pursue arbitration on the basis that courts have altered the law by reaching a decision. This is because the more uncertain the law is, the more likely it may be that the foreign investor "should be compensated in case of regulation" (Janeba, 2019: 25).

\subsection{CETA: A Stepping Stone for Clarifying the Treatment Standards}

Under Article 8.10 of CETA, it is made clear that the required treatment standards are the FET and FPS standards, and both standards have been clarified, thereby limiting the otherwise extensive investment protection for foreign investors, discussed above. Although further published guidance may be useful in order to remove differences in interpretation. Martini's (2018) proposal that Article XX of the General Agreement on Tariffs and Trade could serve as a template for general exception clauses also appears conceivable. Also, a good faith investigation could be undertaken, and this could be tied to scrutinising whether a foreign investor has breached international norms, such as international human rights and environmental rights spelled out in treaties ratified by the host state (Giest, 2017).

\subsection{CETA: A Stepping Stone for Clarifying the Customary Principle of Compensation}

The legal uncertainty which exist in respect of the customary principle of compensation must also be remedied in order to prevent a regulatory chill. Again, CETA offers a possible intermediate solution since it helpfully stipulates that foreign investors receive the same treatment in respect of compensation as is accorded to domestic investors or third country investor, whatever is more favourable, when losses have been occasioned because of "armed conflict, civil strife, a state of emergency or natural disaster." ${ }^{39}$ Moreover, Article 8.12(1)-(6) spells out in which cases a direct or indirect expropriation can take place, stipulates the criteria which need to be considered when determining compensation, imposes a procedural safeguard and delimits what actions in respect of intellectual property rights do not constitute an expropriation, thereby remedying some of the uncertainties of the customary principle. Additionally, Annex 8-A further defines what constitutes an expropriation, including what factors must be born in mind in respect of determining whether there was an indirect expropriation. Yet Annex 8-A, section 3, while providing that there is no indirect expropriation when the non-discriminatory measure was "to protect legitimate public welfare objectives, such as health, safety and the environment", also states that there will be an indirect expropriation when the measure(s) has/have a serious impact. Consequently, "an exception to the exception" has been carved out, thereby undermining the right to regulate in the important area of determining what constitutes an indirect expropriation (Radi, 2017: 4).

\subsection{CETA Provisions: Needed or Unneeded?}

Radi states that the express inclusions of these CETA provisions do "not add much to the protection of States' regulatory freedom", primarily because they also reflect the approach adopted by arbitrators (Radi, 2017: 2\&4). Nonetheless, this paper argues that a multilateral agreement or regional and bilateral IIAs which contain these CETA provisions are likely to promote consistency in decision-making in respect of safeguarding the policy space of host states and thereby remedy the legitimacy problems in respect of investment law cases to some degree (von Walter \& Andrisani, 2019).

\subsection{Moving away from Old Treaties in Three Phases in accordance with UNCTAD's Reform Package}

As reported by UNCTAD, in 2018 over $95 \%$ of IIAs were still "old-generation treaties" which still "bite" and curtail the right of host states to regulate (UNCTAD's Reform Package, 2018: 7). The right to regulate would thus be best protected if governments stopped foreign investors from being overprotected by the "spaghetti bowl system of BITs and IIAs" and strived towards "a harmonized, collective approach" (UNCTAD, 2008: 89). In this context, it is noteworthy that UNCTAD has spelled out the following three different phases in order to reform the international investment regime, so that it "works for all stakeholders" (UNCTAD's Reform Package, 2018: 7): During phase 1, the focus should be on ensuring that IIAs protect the right to regulate, reforming the ISD processes in order to remedy legitimacy issues, facilitating and safeguarding investment, attracting responsible investment, and overcoming inconsistencies and addressing overlaps and gaps within the current system. During phase 2, IIA reform should focus on updating the large amount of old treaties which were entered into prior to 2010, for example, by changing treaty provisions, substituting old treaties, or ending old treaties (UNCTAD's Reform Package, 2018: 7-8). UNCTAD proposes that the third phase of IIA reform should aim to enhance consistency, coherence and relations between various policy makers at the international and national level (UNCTAD's Reform Package, 2018: 8). These different phases may pave the way for the future adoption of a more balanced, stable, clearer and transparent multilateral investment framework, which no longer marginalises the interests of host states and their

39 Article 8.11 of CETA. 
communities (UNCTAD, 2008: 89).

\subsection{Deglobalisation, Covid-19 and Regulatory Chill: New Impetus for Multilateral Solutions}

In the current age of deglobalisation (Tharoor, 2020), it is uncertain whether a comprehensive multilateral solution will be embraced, primarily because international investment law and globalisation are co-dependent (Ferreira, 2020). Furthermore, the Covid-19 pandemic has resulted in a significant drop in FDI and in May 2020, the Organization for Economic Co-operation and Development ('OECD') stated that the most optimistic prediction for 2020 is that FDI flows will fall over 30\% (OECD, 2020). Also, in light of mounting corporate debt it is doubtful whether FDI flows will increase in the longer term (OECD, 2020). Lower FDI flows may possibly dampen interest in working towards a multilateral solution. Also, the measures which states adopted in response to the coronavirus crisis will form the basis for increased international arbitral disputes (Dechert LLP, 2020). Consequently, the COVID-19 pandemic will most likely contribute in a negative way to the regulatory chill of international investment law. Nonetheless, the pandemic also heightens interest in the topic of how "governments [can] shield emergency measures from investor-state arbitration" (Bernasconi-Osterwalder \& Baliño, 2020). Governments may, therefore, not "abandon the idea of international consensus-building for investment altogether" (UNCTAD, 2008: 89). Yet instead of opting for a comprehensive and balanced multilateral solution, governments may opt for a narrower "multilateral agreement [which only]... suspend[s] ISDS for COVID-19 related measures" International Institute for Sustainable Development, 2020: 2). Sornarajah (2020) observes that COVID-19 related investment arbitrations may also result in defences being further developed, such as necessity, as discussed next.

\subsection{Expanding the International Necessity Defence}

The international necessity doctrine could be extended in order to carve out additional protections for host states which need to protect the public good. The necessity doctrine provides states a defence in circumstances where an act, which normally constitutes a wrong, is undertaken to realise a good objective, or is the best choice out of bad options (Boed, 2000). Necessity can thus excuse a state from being found liable for violating treaty and customary international law duties (Kurtz, 2011). However, under customary law the necessity defence ${ }^{40}$ can only be successfully pleaded if strict conditions are satisfied (Gülçür, 2019). This is illustrated by various cases brought against Argentina, such as CMS Gas Transmission Company $v$ Argentina ${ }^{41}$ mentioned above, where Argentina's argument that its financial crisis required emergency measures in order to maintain its public order and safeguard important security interests was rejected (Kurtz, 2011). Hence, to date the doctrine has not been sufficiently utilised in order to protect the policy space of host states, including to validate a violation of an investor right by a national public health law or measure (Marisi, 2020). Accordingly, necessity could be employed to "protect a wide variety of interests, including safeguarding the environment, preserving the very existence of the State and its people in time of [a] public [health] emergency [such as Covid-19], or ensuring the safety of a civilian population." ${ }^{22}$ Further soft law guidance which clarifies the extended scope of the necessity defence (e.g. by providing examples where the defence should succeed) could stimulate informed debate and help with re-envisioning the necessity defence in the investment context, so that the common good, as opposed to primarily commercial interests, are being equally safeguarded (Delany et al., 2018). The development of defences, such as necessity, could thus form part of a far-reaching reform agenda which remedies the "systemic imbalances in the investment regime" (Cotula \& Neal, 2019: 1) in order to prevent the regulatory chill of international investment law.

\subsection{Adopting the Proposals Discussed by the UNCITRAL Working Group III on ISDS Reform}

The solutions put forward by the proposals under discussions at the UNCITRAL Working Group III on ISDS Reform could also be adopted (Cotula \& Neal, 2019). The Working Group has clarified that reform could be realised, either if the system was partially or entirely replaced, or was incrementally changed (Paulsson, 2020). The Working Group's proposals focus on addressing the following concerns: "Lack of consistency, coherence, predictability and correctness of arbitral decisions by ISDS tribunals"; "[a]rbitrators and decision makers"; "[c]ost and duration of ISDS proceedings"; and "[t]hird-party funding." 43 The UNCITRAL Working Group III has recommended that these issues could be addressed, for example, by creating an appellate mechanism ${ }^{44}$; reforming

\footnotetext{
${ }^{40}$ Article 25 of the International Law Commission's Draft articles on Responsibility of States for Internationally Wrongful Acts 2001.

${ }^{41}$ CMS Gas Transmission Company v Argentina, ICSID Case No. ARB/01/8, Award, (Orrego Vicuna, Lalonde, Rezek) (12 May 2005).

${ }^{42}$ International Law Commission's Commentary to Article 25, para. 14; Continental Casualty Company v. Argentine Republic, ICSID, Case No. ARB/ 03/09, 5 September 2008, para.166.

${ }^{43}$ UNCITRAL Working Group III (Investor-State Dispute Settlement Reform) (2019, July 30). Possible reform of investor-State dispute settlement (ISDS). Note by the Secretariat. A/CN.9/WG.III/WP.166, 1-14, 3. Retrieved from https://undocs.org/en/A/CN.9/WG.III/WP.166

${ }^{44}$ UNCITRAL Working Group III (Investor-State Dispute Settlement Reform) (2020). Possible reform of investor-State dispute settlement (ISDS). Appellate mechanism and enforcement issues. Note by the Secretariat, A/CN.9/WG.III/WP, 1-19, 1 .
} 
"the selection and appointment processes for ISDS tribunal members" ${ }^{45}$, and agreeing to a "draft Code of Conduct for investor-State dispute settlement adjudicators" (International Centre for Settlement of Investment Disputes, 2020). However, the ramifications of establishing an appellate mechanism would be that costs will increase, and it will take longer to get a final decision, thereby creating uncertainty which may dampen international trade during times where it should be encouraged (Paulsson, 2020). Also, the emphasis of the recommendations is on reforming "the procedural aspects of ISDS" (Coutla \& Neal, 2019: 1). Therefore, adoption of the proposals would be "a weak compromise between the different perspectives on ISDS", and which according to Verbeek would result in the "broader transnational business interests" being "re-legitimise[d] (Verbeek, 2018). Nonetheless, the reforms will most likely further enhance the quality of the arbitral system and thereby also reduce the "probability of [arbitrators] taking a wrong decision" (Janeba, 2019: 33).

\subsection{Striving to Level the Playing Field by Extending the Rights of Host States}

Recalibrating international investment law in order to prevent its regulatory chill will require an equilibrium in terms of the legal arsenal which is available to both foreign investors and host states. Scholars, such as Laborde, therefore, argue that host states should bring investment arbitration against foreign investors, but while host States can resort to ISDS, this rarely happens (Laborde, 2010). Sauvant \& Ünüvar (2016) recommend that a theory is promulgated under which host states can assert legitimate expectations, thereby improving the way in which the interest of host state and investor interests are balanced. For instance, host states could rely on statements made by foreign investors about the benefits of the investment for the country, written duties assumed by foreign investors, and confirmation of adherence to instruments, such as the OECD Guidelines for Multinational Enterprises, as well as revised and modernised IIAs (Sauvant \& Ünüvar, 2016). While these changes to the investment law framework are likely to contribute to legal uncertainty when resolving investment disputes (Martini, 2018), over time these steps could contribute to a shift within international investment law and the development of new customary international law.

\subsection{Domestic Solutions to Prevent the Regulatory Chill}

At the domestic level, states can terminate IIAs or not include investor-state arbitration provisions, confer fewer protections by virtue of their BITs and include comprehensive exception clauses (Vadi, 2018). Host states should also conduct human rights, social impact and sustainability impact assessments prior to entering into investment agreements in order to identify possible issues which unduly curtail their policy space. ${ }^{46}$

Positive language, for instance, "sustainable development minded elements", can also be included in investment treaties $^{47}$ (Giest, 2017: 337; Martini 2018). However, an exemption or positive language in a BIT does not provide an exception to the customary Hull formula from operating, as illustrated by Copper Mesa Mining Corp. ${ }^{48}$ It also does not create an enforceable right for host states and only fulfils an interpretative role, as made clear in Article 31 of the Vienna Convention on the Law of Treaties, but may help with facilitating that arbitrators assign more weight to public interest concerns (Giest, 2017).

Apart from positive language, investor responsibilities could also be included in IIAs, so that foreign investments do not have an adverse impact, for example, on human and labour rights, the environment, public health or the economy (Sattorova, 2015). Host states could then evoke these responsibilities as part of a counterclaim, as proposed by Guntrip (2018). Although host states would need to clearly spell out the legally binding responsibility, including the scope of the obligation, insert an express legal provision in the investment agreement and additionally refer to the source of the responsibilities (i.e. identify the specific domestic and/or international law and provision in the investment agreement) (Guntrip, 2018). Host states should specifically refer to those rights which were flagged up as particularly at risk by the impact assessments undertaken prior to the conclusion of the investment agreement (Guntrip, 2018).

\section{Conclusion}

This article has explicated why investment agreements can have a regulatory chill, which primarily stems from the threat of ISDS and significant arbitral awards being made against host states. Furthermore, it has been highlighted

\footnotetext{
${ }^{45}$ UNCITRAL Working Group III (Investor-State Dispute Settlement Reform) (2020). Selection and appointment of ISDS tribunal members. Note by the Secretariat. A/CN.9/WG.III/WP, 1-17, 1 .

${ }^{46}$ Report of the Special Rapporteur on the right to food, Olivier De Schutter (2011, December 19). Guiding principles on human rights impact assessments of trade and investment agreements. Human Rights Council, A/HRC/19/59/Add.5, 1-15, 3. Retrieved from https://www.ohchr.org/Documents/HRBodies/HRCouncil/RegularSession/Session19/A-HRC-19-59-Add5_en.pdf

${ }^{47}$ For instance, see Articles 1(3) and Article 24 of the Morocco-Nigeria BIT 2016.

${ }^{48}$ Copper Mesa Mining Corp. v. Republic of Ecuador, PCA Case No. 2012-2, Award (15 March 2016).
} 
that the vague customary international minimum standard and the customary FPS, FET and compensation principles further contribute to the asymmetric relationship which characterises the foreign investor-host state relationship and thereby marginalise host state interests. Cases have been discussed in which regulatory change has resulted in host states being ordered to pay compensation to foreign investors or withdrawing legislation due to the threat of arbitration. Issues with assigning primacy to commercial interests, particularly in respect of ensuring that international investment law retains its legitimacy, have been recognised. Various solutions have been proposed in order to prevent the regulatory chill of investment agreements, although these depend on the political willingness and courage of states to reassert their sovereign rights against powerful transnational commercial parties.

\section{Acknowledgments}

The author acknowledges that he has not received any grants or other financial support for this paper.

\section{References}

Alvarez, J. E. (2016). Is the Trans-Pacific Partnership's Investment Chapter the New "Gold Standard"? Institute for International Law and Justice Working Paper 2016/3, 1-49. Retrieved from https://iilj.org/wpcontent/uploads/2016/08/Alvarez_IILJ_2016_3-MegaReg.pdf

Alvarez, J. E., \& Sauvant, K. P. (2011). The Evolving International Investment Regime: Expectations, Realities, Options. https://doi.org/10.1093/acprof:oso/9780199793624.001.0001

Arcuri, A. (2017, September 30). The Great Asymmetry and the Rule of Law in International Investment Arbitration. In L. Sachs, L. Johnson, \& J. Coleman (Eds.), Yearbook on International Investment Law and Policy 2018 (OUP, 2019 “in press”, pp 1-20). Retrieved from https://ssrn.com/abstract=3152808

Babu, R. R. (2014). Changing Trajectories of Investment Protection in India: An Analysis of Compensation for Expropriation. Trade, Law and Development, 6(2), 359-392.

Berge, T. L., \& Berger, A. (2020, January 20). Do investor-state dispute settlement cases influence domestic environmental regulation? The role of respondent-state capacity, 1-63. Retrieved from https://papers.ssrn.com/sol3/papers.cfm?abstract_id $=3522366$

Bernasconi-Osterwalder, N., \& Baliño, S. (2020, May 21). As COVID-19 Continues, Governments Must Shield Emergency Measures from Investor-State Arbitration. International Institute for Sustainable Development. Retrieved from https://www.iisd.org/articles/covid-19-support-litigation

Bernasconi-Osterwalder, N., \& Johnson, L. (2019, December 17). What to Expect in the January 2020 Session of UNCITRAL Working Group III on ISDS Reform. Retrieved from https://www.iisd.org/itn/2019/12/17/whatto-expect-in-the-january-2020-session-of-uncitral-working-group-iii-on-isds-reform-nathalie-bernasconiosterwalder-lise-johnson/

Boed, R. (2000). State of Necessity as a Justification for Internationally Wrongful Conduct. Yale Human Rights and Development Journal, 3(1), 1-44.

Boeglin, N. (2013, June). ICSID and Latin America: Criticisms, withdrawals and regional alternatives. Retrieved from https://www.bilaterals.org/?icsid-and-latin-americacriticisms\&lang=fr\#: :text=Bolivia $\% 20$ was $\% 20$ the $\% 20$ first $\% 20$ state,became $\% 20$ effective $\% 20$ on $\% 20 J u l y$ $\% 202012$.

Bonnitcha, J. (2011). Outline of a normative framework for evaluating interpretations of investment treaty protections. In C. Brown, \& K. Miles (Eds.), Evolution in Investment Treaty Law and Arbitration. https://doi.org/10.1017/CBO9781139043809

Bonnitcha, J. (2014). Substantive Protection under Investment Treaties. https://doi.org/10.1017/CBO9781107326361

Bryman, A. (2010). Quantitative vs. Qualitative Methods? In A. Giddens, \& P. W. Sutton (Eds.), Sociology: Introductory Readings (3rd ed.). Malden: Polity.

Butler, N., \& Subedi, S. (2017). The Future of International Investment Regulation: Towards a World Investment Organisation? Netherlands International Law Review, 64, 43-72. Retrieved from https://ink.springer.com/article/10.1007/s40802-017-0082-5

Chimni, B. S. (2019). Power and Inequality in Megaregulation: The TPP Mode. In B. Kingsbury, D. M. Malone, P. Mertenskötter, R. B. Stewart, T. Streinz, \& A. Sunami (Eds.), Megaregulation Contested: Global Economic Ordering After TPP. https://doi.org/10.1093/oso/9780198825296.001.0001 
Collins, D. (2017). An Introduction to International Investment Law. https://doi.org/10.1017/CBO9781316675687

Côté, C. (2014). A Chilling Effect? The impact of International Investment Agreements on National Regulatory Autonomy in the Areas of Health, Safety and the Environment (PhD Thesis, London School of Economics, UK). Retrieved from http://etheses.lse.ac.uk/897/

Cotula, L. (2011). Freezing the balancing act? Project finance, legal tools to manage regulatory risk, and sustainable development. In S. Leader, \& D. Ong (Eds.), Global Project Finance, Human Rights and Sustainable Development. https://doi.org/10.1017/CBO9780511974311

Cotula, L., \& Neal, T. (2019, March). UNCITRAL Working Group III: Can Reforming Procedues Rebalance Investor Rights and Obligations? South Centre, No. 15, 1-5. Retrieved from https://www.southcentre.int/wpcontent/uploads/2019/03/IPB15_UNCITRAL-Working-Group-III-Can-Reforming-Procedures-RebalanceInvestor-Rights-and-Obligations_EN-1.pdf

Coyle, S. (2006). Positivism, Idealism and the Rule of Law. Oxford Journal of Legal Studies, 26(2), 257-288. https://doi.org/10.1093/ojls/gq1003

Croisant, G. (2019, April 30). Opinion 1/17 - The CJEU Confirms that CETA's Investment Court System is Compatible with EU Law. Kluwer Arbitration Blog. Retrieved from $\mathrm{http}$ ://arbitrationblog.kluwerarbitration.com/2019/04/30/opinion-117-the-cjeu-confirms-that-cetasinvestment-court-system-is-compatible-with-eu-law/

Dechert LLP (2020, June 20). COVID-19 Economic Crisis: Ensuring Protection for International Banking and Finance Investors and their Investments. International Comparative Legal Guides. Retrieved from https://iclg.com/briefing/13272-covid-19-economic-crisis-ensuring-protection-for-international-bankingand-finance-investors-and-their-investments

Delany, L., Signal, L., \& Thomson, G. (2018). International trade and investment law: a new framework for public health and the common good. BMC Public Health, 18(602). https://doi.org/10.1186/s12889-018-5486-6

Dugan, C., Wallace, D., Rubins, N., \& Sabahi, B. (2008). Investor-State Arbitration. https://doi.org/10.1093/law:iic/9780379215441.book.1

Edwards, R., \& Holland, J. (2013). What is Qualitative Interviewing? London: Bloomsbury.

European Commission. (2014). CETA - Summary of the final negotiating results, 1-19. Retrieved from http://trade.ec.europa.eu/doclib/docs/2014/december/tradoc_152982.pdf

Ferreira, A. (2020). Intertwined paths of globalization and international investment law. Journal of International Trade Law and Policy, 19(2), 85-99. https://doi.org/10.1108/JITLP-01-2020-0010

Franck, T. M. (1998). Fairness in the International Legal and Institutional System. Oxford: Clarendon Press.

García-Salmones Rovira, M. (2015). Faith, Ritual and Rebellion in 21st Century (Positivist) International Law. The European Journal of International Law, 26(2), 537-555. https://doi.org/10.1093/ejil/chv030

Giest, A. (2017). Interpreting Public Interest Provisions in International Investment Treaties. Chicago Journal of International Law, 18(1), 321-352. Retrieved from https://chicagounbound.uchicago.edu/cjil/vol18/iss1/9

Gilmore, A. B., Collin, J., \& McKee, M. (2006). British American Tobacco's erosion of health legislation in Uzbekistan. British Medical Journal, 332-355. https://doi.org/10.1136/bmj.332.7537.355

Gülçür, A. (2019). The Necessity, Public Interest, and Proportionality in International Investment Law: A Comparative Analysis. University of Baltimore Journal of International Law, 6(2), 215-265. Retrieved from https://scholarworks.law.ubalt.edu/cgi/viewcontent.cgi?article=1072\&context=ubjil

Guntrip, E. (2018). A Host State Human Rights Counterclaim in Investment Arbitration. UN Forum on Business and Human Rights, 1-3. $\quad$ Retrieved from https://www.ohchr.org/Documents/Issues/Business/Forum2018Submission7.pdf

Hervey, T., Cryer, R., Sokhi-Bulley, B., \& Bohm, A. (2011). Research Methodologies in EU and International Law. https://doi.org/10.1111/j.1468-0386.2011.00591_2.x

Hindelang, S., \& Krajewski, M. (2016). Shifting Paradigms in International Investment Law: More Balanced, Less Isolated, Increasingly Diversified. Oxford: Oxford University Press.

Hutchinson, T. (2013). Doctrinal research: researching the jury. In D. Watkins, \& M. Burton (Eds.), Research Methods in Law. Abingdon: Routledge. 
International Centre for Settlement of Investment Disputes. (2020, May 1). ICSID and UNCITRAL Release Draft Code of Conduct for Adjudicators. Retrieved from https://icsid.worldbank.org/news-and-events/newsreleases/icsid-and-uncitral-release-draft-code-conduct-adjudicators? $\mathrm{CID}=365$

International Institute for Sustainable Development. (2020, May 4). Virtual meeting on ISDS \& Covid-19 measures, 1-17. Retrieved from https://www.iisd.org/system/files/meterial/presentation_covid_isds_EN.pdf

Janeba, E. (2019). Regulatory Chill and the Effect of Investor State Dispute Settlements. CESifo Working Paper Series No. 6188, 1-38. Retrieved from https://papers.ssrn.com/sol3/papers.cfm?abstract_id=2887952

Ji, J. (2018, May 25). Attacking ISDS provisions for causing regulatory chill: a moving target. Arbitration Blog. Retrieved from http://arbitrationblog.practicallaw.com/attacking-isds-provisions-for-causing-regulatorychill-a-moving-target/

Johnson, L., \& Volkov, O. (2013). Investor-State Contracts, Host-State 'Commitments' and the Myth of Stability in International Law. The American Review of International Arbitration, 24(3), 361-415. Retrieved from https://papers.ssrn.com/sol3/papers.cfm?abstract_id $=2412592$

Johnson, L., \& Volkov, O. (2014, January 6). State Liability for Regulatory Change: How International Investment Rules are Overriding Domestic Law. Investment Treaty News. Retrieved from https://cf.iisd.net/itn/2014/01/06/state-liability-for-regulatory-change-how-international-investment-rulesare-overriding-domestic-law/

Joubin-Bret, A. (2008). Admission and Establishment in the Context of Investment Protection. In A. Reinisch (Ed.), Standards of Investment Protection. Oxford: Oxford University Press.

Junngam, N. (2018). The Full Protection and Security Standard in International Investment Law: What and Who Is Investment Fully [?] Protected and Secured From? American University Business Law Review, 7(1), 1-100. Retrieved from https://papers.ssrn.com/sol3/papers.cfm?abstract_id=3160032

Kanetake, M., \& Nollkaemper, A. (2016). The Rule of Law at the National and International Levels: Contestations and International Levels, Contestations and Deference. Oxford: Hart Publishing.

Kläger, R. (2011). Fair and Equitable Treatment' in International Investment Law. Cambridge: Cambridge University Press.

Knight, J., \& Chapman, S. (2004). "Asia is now the priority target for the world anti-tobacco movement”: attempts by the tobacco industry to undermine the Asian anti-smoking movement. Tobacco Control, 13, ii30-ii36. https://doi.org/10.1136/tc.2004.009159

Kurtz, J. (2011). Delineating Primary and Secondary Rules on Necessity at International Law. In T. Broude, \& Y. Shany (Eds.), Multi-Sourced Equivalent Norms in International Law. Oxford: Hart Publishing.

Laborde, G. (2010). The Case for Host State Claims in Investment Arbitration. Journal of International Dispute Settlement, 1(1), 97-122. https://doi.org/10.1093/jnlids/idp008

Leader, S. (2006). Human rights, risks, and new strategies for global investment. Journal of International Economic Law, 9, 657-705. https://doi.org/10.1093/jiel/jg1015

Mann, H. (2018, October 18). Metalclad v. Mexico. Investment Treaty News. Retrieved from https://cf.iisd.net/itn/2018/10/18/metalclad-v-mexico/

Mantilla Blanco, S. (2019). Full Protection and Security in International Investment Law. London: Springer.

Marisi, F. (2020). Environmental Interests in Investment Arbitration: Challenges and Directions. Alphen aan den Rijn: Wolters Kluwer.

Martini, C. (2018). Avoiding the Planned Obsolescence of Modern International Agreements: Can General Exception Mechanisms Be Improved, and How? Boston College Law Review, 59, 2877-2897. Retrieved from https://lawdigitalcommons.bc.edu/bclr/vol59/iss8/13/

Meyerson, D. (2009). Understanding Jurisprudence. Abingdon: Routledge.

Miles, K. (2013). The Origins of International Investment Law: Empire, Environment and the Safeguarding of Capital. https://doi.org/10.1017/CBO9781139600279

Mitchell, A. D., Heaton, D., \& Henckels, C. (2016). Non-Discrimination and the Role of Regulatory Purpose in International Trade and Investment Law. https://doi.org/10.4337/9781785368097

Morosini, F., \& Sanchez Badin, M. R. (2018). Reconceptualizing International Investment Law from the Global 
South. https://doi.org/10.1017/9781316996812

Nagy, C. I. (2020). World Trade and Local Public Interest: Trade Liberalization and National Regulatory Sovereignty. London: Springer.

Newcombe, A. P., \& Paradell, L. (2009). Law and Practice of Investment Treaties: Standards of Treatment. AH Alphen aan den Rijn: Kluwer Law International.

OECD. (2020, May 4). Foreign direct investment flows in the time of COVID-19. Retrieved from https://www.oecd.org/coronavirus/policy-responses/foreign-direct-investment-flows-in-the-time-of-covid$19-\mathrm{a} 2 \mathrm{fa} 20 \mathrm{c} 4 /$

Páez-Salgado, D. (2015, December 21). Occidental v Ecuador: Partial annulment decision upholds the State's liability. Kluwer Arbitration Blog. Retrieved from http://arbitrationblog.kluwerarbitration.com/2015/12/21/occidental-v-ecuador-partial-annulment-decisionupholds-the-states-liability/?doing_wp_cron=1598665722.7510700225830078125000

Paulsson, M. R. P. (2020, March 26). UNCITRAL Working Group III: Reforms in the Realm of Investor-State Disputes - UNCITRAL's Proposals for an Appellate Mechanism and its Impact on Duration and Cost. Kluwer Arbitration Blog. Retrieved from http://arbitrationblog.kluwerarbitration.com/2020/03/26/uncitral-workinggroup-iii-reforms-in-the-realm-of-investor-state-disputes-uncitrals-proposals-for-an-appellate-mechanismand-its-impact-on-duration-and-cost/

Posner, E. A., \& Sykes, A. O. (2012). Economic Foundations of International Law. https://doi.org/10.4159/harvard.9780674067639

Public Citizen. (2001). NAFTA Chapter 11 Investor-to-State Cases: Bankrupting Democracy, 1-70. Retrieved from https://www.citizen.org/wp-content/uploads/acf186.pdf

Radi, Y. (2017). ESIL Reflection 'Much Ado About Nothing'? An Appraisal of CETA's Investment Chapter. European Society of International Law Reflections, 6(4), 1-8. Retrieved from https://esil-sedi.eu/wpcontent/uploads/2017/05/ESIL-Reflection-Radi.pdf

Ripinsky, S., \& Williams, K. (2008). Case summary, CMS Gas Transmission Company v Argentina. British Institute of International and Comparative Law, 1-9. Retrieved from https://www.biicl.org/files/3913_2005_cms_v_argentina.pdf

Ripinsky, S., \& Williams, K. (2008). Damages in International Investment Law. London: British Institute of International and Comparative Law.

Sasse, J. P. (2011). An Economic Analysis of Bilateral Investment Treaties. London: Springer.

Sattorova, M. (2019). Investor Responsibilities from a Host State Perspective: Qualitative Data and Proposals for Treaty Reform. American Journal of International Law, 113, 22-27. https://doi.org/10.1017/aju.2018.93

Sauvant, K. P., \& Ünüvar, G. (2016). Can Host Countries Have Legitimate Expectations? Columbia Center on Sustainable Investment No. 183, 1-4. Retrieved from http://ccsi.columbia.edu/files/2013/10/No-183Sauvant-and-\%C3\%9Cn\%C3\%BCvar-FINAL.pdf

Scherer, M. (2018). International Arbitration in the Energy Sector. https://doi.org/10.1093/law/9780198805786.001.0001

Schill, S. W. (2007). Do Investment Treaties Chill Unilateral State Regulation to Mitigate Climate Change? Journal of International Arbitration, 24(5), 469-477.

Sornarajah, M. (2017). The International Law on Foreign Investment (4th ed.). https://doi.org/10.1017/9781316459959

Sornarajah, M. (2020, August 11). The Covid-19 pandemic and liability under investment treaties. Retrieved from https://www.bilaterals.org/?the-covid-19-pandemic-and

Suda, R. (2006). The Effect of Bilateral Investment Treaties on Human Rights Enforcement and Realization. In O. De Schutter (Ed.), Transnational Corporations and Human Rights. Oxford: Hart Publishing.

Thakur, T. (2020). Reforming the investor-state dispute settlement mechanism and the host state's right to regulate: a critical assessment. Indian Journal of International Law. Retrieved from https://link.springer.com/article/10.1007\%2Fs40901-020-00111-2

Tharoor, S. (2020, June 28). An era of deglobalisation? The Week. Retrieved from https://www.theweek.in/columns/shashi-tharoor/2020/06/18/an-era-of-deglobalisation.html 
Tienhaara, K. (2011). Regulatory Chill and the Threat of Arbitration: A View from Political Science. In C. Brown, \& K. Miles (Eds.), Evolution in Investment Treaty Law and Arbitration. Cambridge: Cambridge University Press (pp 1-28). Retrieved from https://papers.ssrn.com/sol3/papers.cfm?abstract_id=2065706

Torgal, L. (2020). The Multilateral Investment Court Project: The 'Judicialization' of Arbitration? Garrigues. Retrieved from https://www.garrigues.com/en_GB/new/multilateral-investment-court-projectjudicialization-arbitration

Turinys, P. (2016). CETA: EU and Canada agree on new approach on investment in trade agreement. European Commission. Retrieved from https://ec.europa.eu/commission/presscorner/detail/lt/IP_16_399

UNCTAD. (2008). International Investment Rule-Making: Stocktaking, Challenges and the War Forward. United Nations, 1-125. Retrieved from https://unctad.org/en/Docs/iteiit20073_en.pdf

UNCTAD. (2018). UNCTAD's Reform Package for the International Investment Regime, Phase 1, Phase 2, Phase 3 (2018 Edition), 1-122. Retrieved from https://investmentpolicy.unctad.org/publications/1190/unctad-sreform-package-for-the-international-investment-regime-2018-edition-

Urueña, R. (2012). No Citizens Here: Global Subjects and Participation in International Law. https://doi.org/10.1163/9789004220706

Vadi, V. (2018). Proportionality, Reasonableness and Standards of Review in International Investment Law and Arbitration. https://doi.org/10.4337/9781785368585

Van Harten, G. (2005). Private authority and transnational governance: the contours of the international system of investor protection. Review of International Political Economy, 12, 600-623. https://doi.org/10.1080/09692290500240305

Verbeek, B.-J. (2018, October 31). The limitations of the UNCITRAL process on ISDS reform. Global Policy Forum. Retrieved from https://www.globalpolicy.org/home/270-general/53076-the-limitations-of-the-uncitralprocess-on-isds-reform.html

Vinod, M. J., \& Deshpande, M. (2013). Contemporary Political Theory. New Delhi: PHI Learning Private Ltd.

von Moltke, K. (2000). An International Investment Regime? Issues of Sustainability. International Institute for $\begin{array}{llll}\text { Sustainable Development, } & 1-88 . & \text { Retrieved }\end{array}$ https://www.iisd.org/sites/default/files/publications/investment.pdf

von Walter, A., \& Andrisani, M. L. (2019). Resolution of Investment Disputes. In M. M. Mbengue, \& S. Schacherer (Eds.), Foreign Investment Under the Comprehensive Economic and Trade Agreement (CETA). London: Springer.

\section{Copyrights}

Copyright for this article is retained by the author(s), with first publication rights granted to the journal.

This is an open-access article distributed under the terms and conditions of the Creative Commons Attribution license (http://creativecommons.org/licenses/by/4.0/). 